\title{
マダラカゲロウ属の幼若幼虫が砂底に みられるとと
}

津田松苗

Occurence of young larvae of Ephemerella

in sandy bottom of stream.

By Matsunae TsudA

Ephemerella マダラカゲロウの幼虫は扁平甸匍型でふつう川の瀬の石底にみられる. 早 瀬，平瀬の石に大形の (成熟した) 幼虫や中形の幼虫がみられるのである.

一方, 岸近くの, 流れの緩いところは砂底になるが, そのようなところには大きい幼虫 は決してみられない，ところが，このような砂底にも小さい（幼若な）幼虫は生息してい る場合のあるのに気がついた.

たとえば昭和 41 年 4 月 29 日, 大和吉野川の上流, 吉野郡川上村筏場地点の岸の砂底の例 であるが，写真 2 のリトリ型金網ですくつてある砂のなかから，写真 1 に示す73個体の

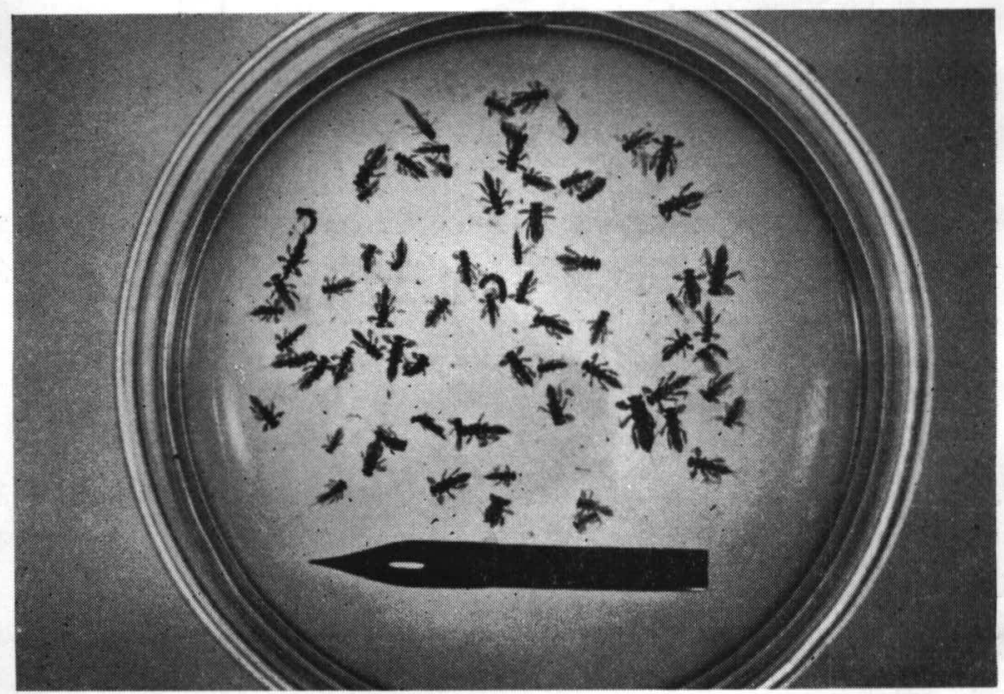

写真 1 


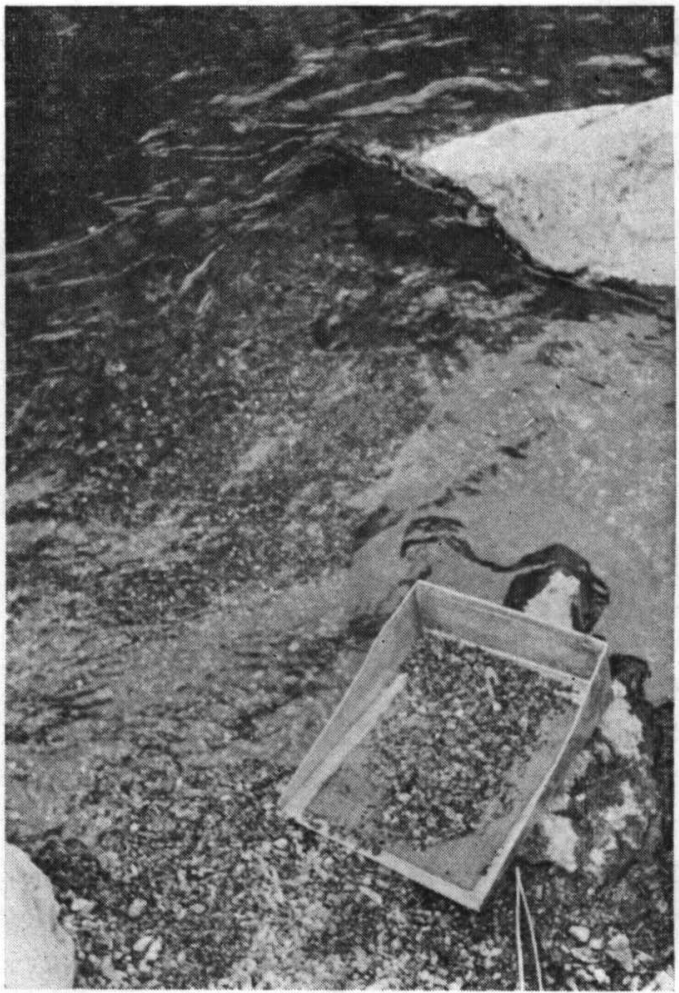

写真 2

カゲロウ幼虫が発見された. 金網の一番手前の一辺は $25 \mathrm{~cm}$ であるから, その砂の量も見 当がつくと思う.この少量の砂のなかにかなり多くの個体数がおるのである，この場合の 種類とその個体数を示すと

$\begin{array}{ll}\text { Ephemerella } & \text { 70個体 } \\ \text { Ecdyonurus } & \text { 2個体 } \\ \text { Baetis } & \text { 1個体 }\end{array}$

で, Ephemerella が大多数を占めている. 写真の丸ペンの長さは $31 \mathrm{~mm}$ で, これとく らべてわかるように, 奻虫はいずれも体長 $2.5 \sim 3.5 \mathrm{~mm}$ 程度の幼若のものばかりである.

以上は 1 例であるが, このようなことから次のことが考察される.

1. このような Ephemerella の幼若幼虫にとつては砂底でも十分その好適な生息場所 であることが知られる。大きくなつた幼虫には不適な環境でも幼若幼虫には好適な環境な のだ. 
2. また，大きい㓜虫には必要な大きい㐬速を，小さい幼虫は必ずしも必要としないこ とが若妄ら动る。

3. Ephemerella 成虫によつて産み出された射から躬化した勻虫はまず流れの緩い砂底 にとどまる。そして大きくなるにつれ，流狆の強い瀬の百の底に移ることになると思われ 吕.

4.ただし以上のことは，どの川の部分でも妥当するとはいえない，現に，吉野川のこ の調植の際に，これより下流の，入の波地点，陎山地点等では，砂底でこのような幻若幻 虫の生息をみること忹なかつた，砂底でも条件がよくなければならない，㳸や有機简泥や 微生物・薄類の死䯓などを含まない仯底でなければなら去うだ、それに，砂が躍るよう でもいけない.

5. 一方，この岸よりの砂地に残つているのは Ephemerella が大部分で Epeorus はい ないし，Ecdyonurusもごくわずかであることに注意がひかれる．Epeorusは Ephemerella よりもさらに扁平でさらに流れに強く，この程度の大きさの刈虫も早瀬に行つてしまい， 流れの緩い秒地にはとどまらないのである，実際，早瀬の石の裏側にEpeorus の小さい妃 虫をたさえみることができるのである。

(筆者：津田松苗，奈良女子大学理学部珵物学教室，奈良市：Matsunae TsuDA, Zoological Institute, Faculty of Science, Nara Women's University, Nara City).

\section{杂隹報}

近畿支部例会をつぎのとおり開催した。

日 時 昭和 41 年 5 月 7 日(土） 4後 2 時 $~ 4$ 時 30 分

ところ 大津市下限本町 京都大学 大津臨湖実験所

講 演

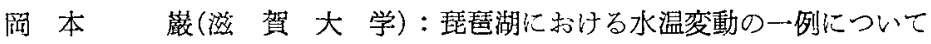

山田満 里(奈良女子大学) : 猪名川水系の污水生物学的研究

六 山 正孝(八尾市成法中学)：吉野川のトンボ幼虫の分布

鈴 木 紀 雄 (大津臨湖実験所) : 淡水魚の鰓の形態的変異 